\title{
Review
}

Neuropsychobiology

Neuropsychobiology 2018/2019;78:70-78

Received: January 21, 2019

DOI: $10.1159 / 000499714$

Accepted after revision: March 19, 2019

Published online: May 16, 2019

\section{Clinically Relevant Anti-Neuronal Cell Surface Antibodies in Schizophrenia Spectrum Disorders}

\author{
Mark Ainsley Colijn ${ }^{\mathrm{a}}$ Zahinoor Ismail ${ }^{\mathrm{a}-\mathrm{c}}$ \\ ${ }^{a}$ Department of Psychiatry, University of Calgary, Calgary, AB, Canada; ${ }^{b}$ Mathison Centre for Mental Health \\ Research and Education, University of Calgary, Calgary, AB, Canada; ${ }^{C}$ Hotchkiss Brain Institute, University of \\ Calgary, Calgary, AB, Canada
}

\section{Keywords}

Autoimmune encephalitis · Psychosis · Schizophrenia ·

Antibodies · Neuropsychiatry

\begin{abstract}
Schizophrenia is a phenotypically heterogeneous and poorly understood disorder. While its etiology is likely multifactorial, immune system dysfunction has increasingly been implicated in its development. As hallucinations and delusions occur frequently and prominently in autoimmune encephalitis $(A E)$, numerous studies have sought to determine whether a small subset of individuals diagnosed with schizophrenia possess anti-neuronal antibodies implicated in AE. Exploring this possibility is of clinical relevance, as identifying individuals with AE who have been misdiagnosed as having a primary psychotic disorder may allow for the implementation of appropriate immune-related therapies as early as possible in the course of the illness, in order to optimize outcomes, reduce illness chronicity, and minimize adverse events. This qualitative review serves to provide an overview of the existing literature on this topic, as well as to update previously published reviews. Although there is some evidence to suggest that in rare cases $A E$ may be misdiagnosed as a primary psychotic disorder, particularly early in the course of the ill-
\end{abstract}

ness, numerous methodological differences between studies likely account for the highly variable findings, and interpretation of the results is particularly limited by a paucity of cerebrospinal fluid data. Moreover, the prevalence of misdiagnosis in chronic and treatment-resistant populations remains understudied. This is particularly problematic, as treatment resistance may represent an enriched population with respect to the presence of anti-neuronal antibodies, and given that such patients have few evidence-based treatment options available to them beyond clozapine.

(c) 2019 S. Karger AG, Basel

\section{Introduction}

Schizophrenia is a phenotypically heterogeneous and potentially debilitating illness [1]. While a variety of etiological and pathophysiological abnormalities have been implicated in its development, it remains a poorly understood disorder [2]. In recent years, multiple lines of evidence have identified, albeit inconsistently, a variety of immune system abnormalities in individuals diagnosed with schizophrenia spectrum disorders, including elevated levels of pro-inflammatory cytokines, abnormalities in $\mathrm{T}$ cells, and evidence of increased microglial activity [3].

\section{KARGER}

(c) 2019 S. Karger AG, Basel

E-Mail karger@karger.com

www.karger.com/nps
Mark Ainsley Colijn

Department of Psychiatry, University of Calgary

1403-29 Street NW

Calgary, Alberta T2N 2T9 (Canada)

E-Mail Mark.colijn2@ucalgary.ca 
Moreover, the risk alleles most strongly associated with schizophrenia in genome-wide association studies map onto the major histocompatibility complex, a region of chromosome 6 that contains numerous genes known to have immune-related functions [4]. There is also limited evidence to suggest that a number of anti-inflammatory agents may be efficacious in treating the symptoms of schizophrenia when used adjunctively with antipsychotics [3]. However, perhaps the most clinically relevant example of the association between the immune system and psychosis is that of autoimmune encephalitis (AE). AE refers to a group of autoimmune disorders characterized by the generation of antibodies directed against a variety of neural substrates in the brain, resulting in a constellation of symptoms that may include any combination of cognitive changes, seizures, abnormal movements, autonomic instability, and an altered level of consciousness, often in addition to early and prominent symptoms of psychosis [5-7]. While diagnostic criteria that rely on neurological examination and standard diagnostic tests have recently been developed in order to facilitate the prompt diagnosis and treatment of $\mathrm{AE}$ [8], isolation of antibodies in the serum and cerebrospinal fluid (CSF) allows for diagnostic confirmation and refinement. AE can be broadly divided into two categories, according to whether the antigenic target is intracellular or extracellular (cell surface) [5]. The intracellular type is usually neoplastic in nature, whereas extracellular AE may or may not be associated with cancers [5]. Additionally, only in the extracellular form are the antibodies thought to be directly pathogenic, and this variety of $\mathrm{AE}$ is associated with a better prognosis [5]. The most commonly tested and clinically relevant extracellular antibodies are of the immunoglobulin $\mathrm{G}(\mathrm{IgG})$ isotype and are directed against the following proteins: $\mathrm{N}$-methyl-D-aspartate receptor (NMDAR), leucine-rich glioma inactivated-1 (LGI1), contactin-associated protein-2 (CASPR2), alpha-amino-3-hydroxy-5-methyl-4-isoxazole propionic acid receptor (AMPAR), gamma-aminobutyric acid $B$ receptor $\left(G_{A B A} R\right)$, and dipeptidyl-peptidase-like protein-6 (DPPX). The NMDA and AMPA receptors are ionotropic glutamate receptors, LGI1, CASPR2, and DPPX are proteins associated with voltagegated potassium channels (VGKC), and $\mathrm{GABA}_{\mathrm{B}} \mathrm{R}$ is a type of metabotropic GABA receptor.

Due to the prominence of psychotic symptoms in AE, and given that psychosis may be the first clinical manifestation of the illness [6], there is concern that AE may be misdiagnosed as schizophrenia in a subset of patients. This is important given that the treatments for the two disorders differ; whereas schizophrenia is primarily man- aged using antipsychotic medications that have variable actions on an array of neurotransmitter receptors [9], AE is known to respond to treatments targeting the immune system, including steroids, intravenous immunoglobulin, and plasmapheresis. As such, it is imperative that psychiatrists consider the possibility of AE when confronted by atypical signs and/or symptoms that are inconsistent with a diagnosis of a primary psychotic disorder. Atypicality may relate to age of onset, rapidity of symptom development, the sensory modality within which perceptual disturbances occur, or the presence of uncommon or unusual associated symptoms, particularly neurological symptoms, such as those mentioned previously. However, even in the absence of atypicality, concern exists that misdiagnosis may still occur in rare cases. This is a particularly worrisome possibility in chronic and treatmentresistant populations, where the correct and underlying diagnosis of AE may not ever be expected to declare itself, based on our conventional phenotypic conceptualization of the disease. If true, it stands to reason that such patients may never have access to indicated and potentially effective immune-related treatments. With all of this in mind, this review is meant to summarize the existing literature that has examined the prevalence of anti-neuronal cell surface antibodies, commonly implicated in $\mathrm{AE}$, in schizophrenia spectrum populations.

This review aims to categorize the results of all previous studies that have tested schizophrenia populations for antineuronal antibodies, according to antibody positivity for each antigenic target, relevant receptor subunit, and immunoglobulin isotype, while differentiating between serum and CSF samples, in the context of control data, where available. Also, this review serves as a timely update as multiple studies, including two that report CSF findings, have been published very recently. Previous meta-analyses will also be summarized. We have chosen to limit our review to include research involving only those antibodies that are associated with well-described encephalidities for which laboratory testing is commercially available, as these represent the most clinically relevant illnesses that may underlie a subset of patients diagnosed with schizophrenia. Nonetheless, it is important to note that the studies reviewed here used variable methods for antibody detection, and this will be addressed where relevant.

Our literature search was conducted in February 2019. Only English-language papers were retrieved using PubMed, and search terms included: "autoimmune", "autoimmunity", "autoimmune encephalitis", "antibodies", "NMDA", "AMPA", "GABA ${ }_{B}$ ", "CASPR2", "LGI1", or "DPPX", in combination with the terms "schizophrenia", 
Fig. 1. PRISMA flow diagram.

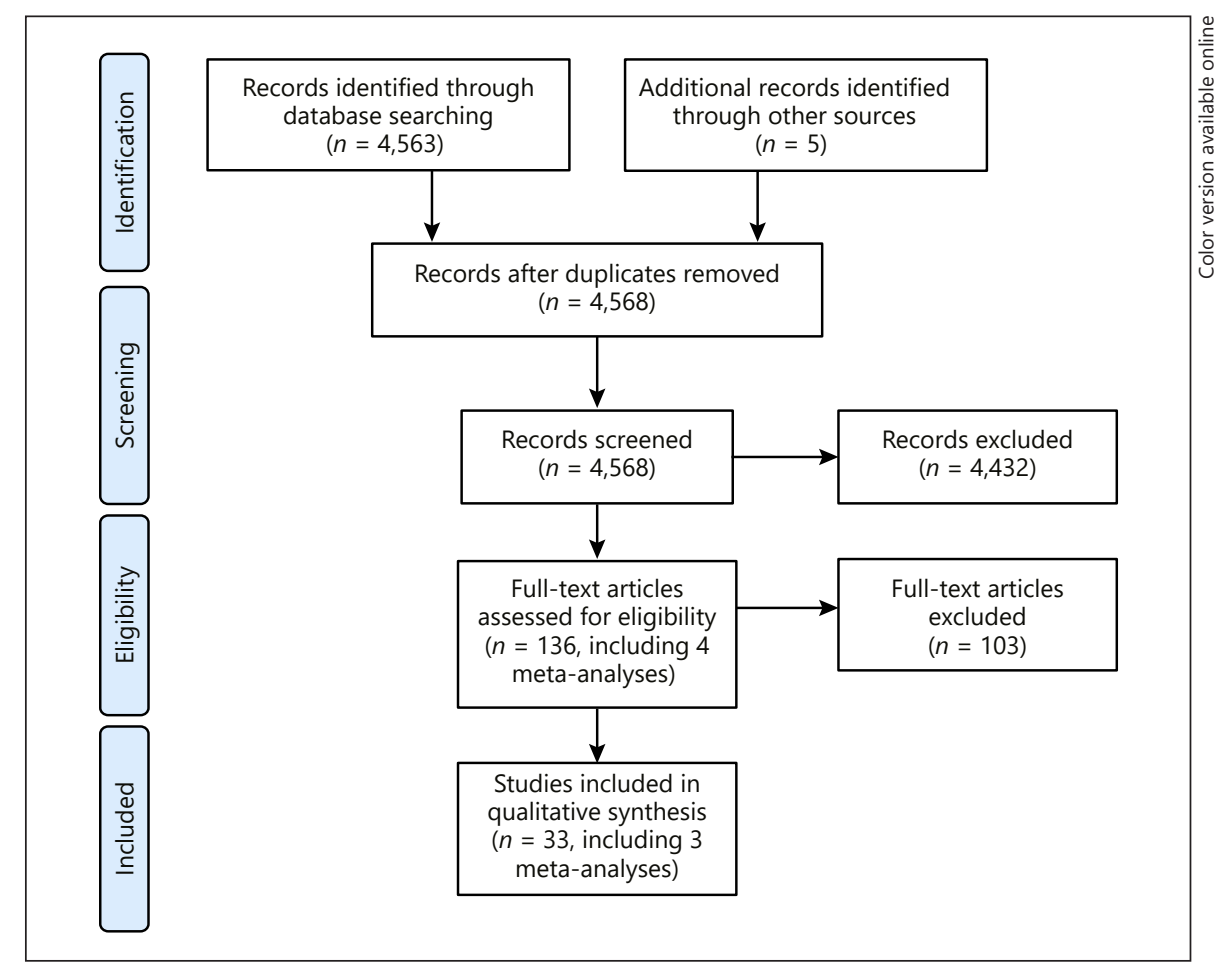

"psychosis", "psychotic", "hallucinations", or "delusions". Reference lists of retrieved papers, including review papers and meta-analyses, were screened for additional papers of relevance. Only articles involving human participants were included. Only studies that tested the CSF and/or serum of individuals diagnosed with a primary psychotic disorder for at least one of the aforementioned anti-neuronal antibodies were included. All but three retrieved studies, which used their own inclusion criteria for defining a first episode of psychosis, reported using the Diagnostic and Statistical Manual of Mental Disorders (DSM) or the International Classification of Diseases (ICD) diagnostic criteria for primary psychotic disorder diagnoses. A total of 4,568 articles were identified and screened, and 33 articles, including three meta-analyses, were deemed appropriate and were included in the review (Fig. 1).

\section{Results}

\section{Serum Studies}

Results from studies that have screened the serum of individuals with schizophrenia spectrum disorders for the aforementioned antibodies have produced mixed results. The results of such studies are organized according to antibody.

\section{Anti-NMDAR}

While some studies have found IgG antibodies directed against the NMDAR NR1 subunit in a small subset of individuals with schizophrenia spectrum disorders (0.6$11.6 \%)$ [10-16], other studies have not [17-29]. The frequency of antibody positivity was around $5 \%$ or less in all but one study [13] and was less than $1 \%$ in two studies $[11,12]$. Of the studies that produced positive results, five included a healthy control group for comparison [10-13, 15], and two of these studies, in addition to further testing in one of them, also identified antibodies in $0.4-1.2 \%$ of healthy controls $[11,12,30]$, making interpretation of the results difficult. No group differences in seroprevalence were found, where reported.

Neither the specific antibody detection methods used nor the diagnostic variability across studies appear to account for the discrepant results. Of the seven positive studies, four used a commercially available fixed cell-based assay (CBA) [10-12, 16], two used a live CBA $[13,15]$, and one used both, as well as a single molecule-based imaging method, for the sake of comparing approaches [14]. The majority of negative studies also used the same aforementioned commercially available CBA (or a modification of it) [17-22, 24-29], and four of these studies also included immunohistochemistry for further testing [19, 26-28]. Two negative studies, including one previously referenced 
study that also used the commercial CBA kit for testing some of its sample, used in-house CBAs [22, 23]. Similarly, consideration of the antibody detection method used in only those positive studies that included a healthy control group for comparison is mostly unrevealing. Specifically, a fixed CBA was used in the two studies that found seropositivity among both healthy control and patient groups [11, 12], as well as in one of the three studies that only found seropositivity in the patient group but not in the control group [10]; the other two studies used live CBAs $[13,15]$. However, it should be noted that the follow-up study to that by Steiner et al. [10] did also find seropositivity in a small number of control participants using the same commercially available fixed CBA [30].

As many of the studies that yielded positive results included a diagnostically heterogeneous sample of primary psychotic disorder patients, but did not report which specific diagnostic groups accounted for the observed seropositivity, it remains unclear to what degree diagnostic variability among studies may have contributed to the conflicting results. Nonetheless, given the available information, diagnostic differences between samples do not appear to be responsible. For instance, although the vast majority of negative studies included patients with DSM IV, DSM IV-TR, DSM 5, or ICD-10 schizophrenia diagnoses, among numerous other diagnoses, so too did most of the positive studies $[10-12,14,16]$, and two of these studies explicitly reported finding antibody positivity in patients with a diagnosis of schizophrenia [10, 14]. Additionally, although the other two positive studies did not report antibody positivity results according to diagnosis, they only included patients with schizophrenia and schizoaffective disorder $[11,12]$. Other diagnoses explicitly reported to be associated with antibody positivity include cannabis-induced psychosis, "acute and transient psychotic disorder" and bipolar affective disorder [16], schizophreniform disorder [14, 16], and first-episode psychosis, defined as having a score of at least 4 on one of numerous positive symptom Positive and Negative Syndrome Scale (PANSS) items [15]. Finally, no clear diagnostic pattern emerges when comparing those studies that found seropositivity in patients but not in healthy controls to those that found seropositivity in both groups. The former included patients with first-episode schizophrenia [10], first-episode psychosis, defined according to the aforementioned criteria [15], and a paediatric sample comprised of patients with a "schizophrenia spectrum disorder" or "affective psychosis" [13], and the latter included patients with schizophrenia or schizoaffective disorder $[11,12]$.

Anti-Neuronal Antibodies in

Schizophrenia
A number of studies have also found immunoglobulin A (IgA) or immunoglobulin $\mathrm{M}(\operatorname{IgM})$ antibodies in a small proportion of patients $(2.3-6.6 \%)[10-13,24]$; a finding of unknown clinical significance. These antibodies were also found in a small proportion of healthy controls (0.4-6.3\%) in all but one of the studies that included a control group [10-12], further complicating interpretation of the results. Additionally, one study that screened for IgA and IgM antibodies was negative [27]. Finally, a few other studies that either screened for antibodies against the NR1a/NR2b receptor subunit [10, 31], NR2a/ NR2b subunit [32], or non-specifically for both NR1 and NR2 subunits [33-36], have found seropositivity in a small percentage of patients. As only antibodies directed against the NR1 subunit are known to produce anti-NMDAR encephalitis, the clinical relevance of these findings remains unclear.

\section{Anti-AMPAR}

Results have been less compelling for anti-AMPAR antibodies, as the majority of studies have been negative $[10,15,18,20,23,26,28,29]$. Moreover, in each of the two positive studies, antibodies were found in only one patient $(<1 \%$ of the samples) $[11,24]$, and the only study that included a healthy control group also found antibodies in $0.2 \%$ of controls [11]. Notably, of these two studies, only Schou et al. [24] specified testing for antibodies of the $\operatorname{IgG}$ isotype.

\section{Anti-LGI1/Anti-CASPR2}

A number of studies that tested for IgG, IgA, or IgM anti-CASPR2 antibodies found seropositivity in a small percentage $(2.5 \%$ or less) of patients $[11,15,24$, $29,36]$, although numerous other studies were negative $[16,18,20,26,28]$. Of note, all of the positive studies that included a healthy control group, however, also found antibodies in a small number of controls (up to $2.9 \%)$, and no group differences were found $[11,15,36]$.

Only three studies found anti-LGI1 antibodies in a small subset of schizophrenia spectrum disorder patients $(2.0 \%$ or less) $[11,15,36]$, whereas six studies were negative $[16,18,20,24,26,29]$. All of the positive studies included a healthy control group for comparison, two of which found anti-LGI1 antibodies in a small number of healthy controls ( $2 \%$ and $<0.1 \%$, respectively), and no group differences were found $[11,36]$.

Anti-GABA $A_{B} R$

All six studies that have screened for antibodies against $\mathrm{GABA}_{B} \mathrm{R}$ have been negative $[11,18,24,26,28,29]$.

Neuropsychobiology 2018/2019;78:70-78 DOI: $10.1159 / 000499714$ 


\section{Anti-DPPX}

Only two studies have screened for antibodies against DPPX. While one study was negative [28], the other study found only one positive case in both the schizophrenia group as well as the healthy control group [11]. In both groups this represented less than $0.1 \%$ of the individuals tested.

\section{Meta-Analyses}

Three meta-analyses have been completed over the past few years to help make sense of the variability in the aforementioned serum results. With respect to the antibodies of interest in this paper, all three of the meta-analyses included only NMDAR antibody data in their analyses [37-39], and none were published recently. As such, many of the aforementioned studies are not captured by these metaanalyses. Nonetheless, although the approaches differed somewhat, all three studies found some evidence of significantly increased NMDAR antibody seropositivity in psychotic patients in comparison to controls. However, one of these studies also found significant results when comparing bipolar disorder and major depressive disorder groups to controls [38]. Interestingly, likely in part due to methodological differences, while Pearlman et al. [38] concluded that their positive findings were not due to an increased prevalence of IgG antibodies in these patient groups, the antibody isotype responsible for causing antiNMDAR encephalitis, Pollak et al. [39] found that only IgG antibodies, and not IgA or IgM antibodies, were more prevalent in psychotic patients in comparison to controls.

\section{CSF Studies}

To date, four studies that have screened individuals with schizophrenia spectrum disorders for the aforementioned antibodies have included CSF findings $[10,16,29$, $40]$, and three have yielded positive results $[10,16,40]$. The methodological details of these studies are outlined in $\mathrm{Ta}$ ble 1. The first study, published by Steiner et al. [10], utilized samples from a blood bank, and initially tested only the serum of 121 schizophrenia patients for IgG, IgA, and IgM antibodies against the NMDA and AMPA receptors. CSF testing was subsequently completed in IgG-seropositive cases, which included four participants with antibodies against the NMDA receptor, two of which had antibodies against the NR1a receptor subunit and two against the NR1a/NR2b subunit. CSF testing confirmed antibody positivity for the two NR1a-positive patients, and these individuals were reclassified as having anti-NMDAR encephalitis. Although neurological symptoms did eventually develop in each case, both individuals had experienced a prior episode of psychosis. Of note, it is reported that one of these patients received immunotherapy after the diagnosis of anti-NMDAR encephalitis was made, and subsequently clinically improved. Scott et al. [16] prospectively screened the serum of 113 first-episode psychosis patients for IgG antibodies against the NMDAR and VGKC, and in seropositive cases referrals to neurological or immunological services were made for consideration of further evaluation and treatment. Four participants were seropositive for anti-neuronal antibodies against the NMDA receptor; in three of these four participants, antibodies were also found in the CSF. Within a week, two of these participants quickly developed neurological symptoms consistent with an encephalitis, whereas one continued to only have psychiatric symptoms; the duration of untreated psychosis for this individual was 70 days. All three individuals reportedly achieved remission of their psychotic symptoms following immunotherapy. One additional participant was seropositive for anti-VGKC antibodies, although CSF testing was negative. Interestingly, however, this individual also reportedly responded to immunotherapy. In contrast to relying on seropositivity to guide CSF analysis, two retrospective studies reported the results of CSF testing in all participants, where possible. The first of these included psychotic patients who had a variety of diagnoses; CSF results for IgG NMDAR and VGKC antibodies were available for 125 participants, and 96 participants were tested for AMPAR and $\mathrm{GABA}_{B} \mathrm{R}$ antibodies [40]. In four cases, antibody testing was positive (three for anti-VGKC and one for anti-NMDAR), and these participants had been diagnosed with either a "schizophreniform syndrome" or a "schizoaffective syndrome". Further clinical details, however, including duration of illness or subsequent treatment with immunotherapy, were not provided. Of note, only one of these individuals (who was positive for VGKC antibodies) had exclusively psychiatric symptoms, without any eventual neurological manifestation of their illness. Lastly, Oviedo-Salcedo et al. [29] retrospectively evaluated CSF anti-neuronal antibody data in 124 individuals with schizophrenia spectrum disorders, some of whom also had results from serum testing available. The sample included both first-episode patients as well as those with recurrent illness, and $24.2 \%$ of the sample had reportedly received clozapine previously. None of the participants had any neurological signs or symptoms suggestive of AE. Antibodies tested included those against NMDAR, AMPAR,

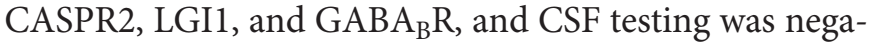
tive in all cases. In two cases, low-titre antibodies against CASPR2 were found in the serum. Of note, none of these studies included control CSF data for comparison.
Colijn/Ismail 
Table 1. Details of the studies that included CSF testing for anti-neuronal antibodies

\begin{tabular}{|c|c|c|c|c|c|c|c|c|}
\hline $\begin{array}{l}\text { First author, } \\
\text { year }\end{array}$ & Antibody analysis & Sample size & Diagnosis & $\begin{array}{l}\text { Illness } \\
\text { duration }\end{array}$ & Design & Control group & CSF results & $\begin{array}{l}\text { Treatment } \\
\text { response }\end{array}$ \\
\hline $\begin{array}{l}\text { Scott et al. } \\
{[16], 2018}\end{array}$ & $\begin{array}{l}\text { NMDAR, CASPR2, } \\
\text { and LGIl antibody } \\
\text { testing was by a } \\
\text { commercial } \\
\text { immunoassay } \\
\text { (Euroimmun); } \\
\text { low positive } \\
\text { anti-NMDAR } \\
\text { results were } \\
\text { detected by weak } \\
\text { immunofluorescence } \\
\text { staining; VGKC anti- } \\
\text { body testing was also by } \\
\text { a commercial } \\
\text { immunoassay (RSR) }\end{array}$ & $\begin{array}{l}113 \text { had serum } \\
\text { testing and } \\
\text { only } \\
\text { seropositive } \\
\text { cases had CSF } \\
\text { testing }(n=5)\end{array}$ & $\begin{array}{l}\text { All were FEP; whole } \\
\text { sample contained a } \\
\text { variety of diagnoses; } \\
\text { seropositive cases included } \\
\text { cannabis-induced } \\
\text { psychosis (CSF } \\
\text { anti-NMDAR+), } \\
\text { acute and transient } \\
\text { psychotic disorder } \\
\text { (CSF anti-NMDAR+), } \\
\text { schizophreniform disorder } \\
\text { (CSF anti-NMDAR low+), } \\
\text { bipolar affective disorder } \\
\text { (CSF-), and first episode } \\
\text { of psychosis (CSF-) }\end{array}$ & $\begin{array}{l}\text { For whole } \\
\text { sample (most } \\
\text { of which did } \\
\text { not have CSF } \\
\text { results), median } \\
\text { DUP = } 30 \text { days } \\
\text { (range } 1-2,340 \\
\text { days); DUP of } \\
\text { CSF- cases = } 2 \\
\text { days; DUP of } \\
\text { CSF+ cases = 5, } \\
7 \text {, and } 70 \text { days }\end{array}$ & Prospective & None & $\begin{array}{l}\text { anti-NMDAR: } \\
3 / 4+(1 \text { of } \\
\text { which was } \\
\text { low+); } \\
\text { anti-VGKC: } \\
0 / 1+\text { for } \\
\text { anti-LGI1 or } \\
\text { anti-CASPR2 }\end{array}$ & $\begin{array}{l}\text { In all } 3 \text { CSF+ } \\
\text { cases, psychosis } \\
\text { resolved in } \\
\text { response to } \\
\text { immunotherapy } \\
\text { and remained in } \\
\text { remission at } \\
\text { follow-up } \\
\text { (between } 2 \\
\text { years and } 6 \\
\text { months and } \\
3 \text { years and } \\
9 \text { months) }\end{array}$ \\
\hline $\begin{array}{l}\text { Endres et al. } \\
{[40], 2015}\end{array}$ & $\begin{array}{l}\text { From } 2011 \\
\text { onward, all cell } \\
\text { surface } \\
\text { anti-neuronal } \\
\text { antibody testing } \\
\text { was by a } \\
\text { commercial } \\
\text { immunoassay } \\
\text { (Euroimmun); } \\
\text { prior to 2011, } \\
\text { testing took place } \\
\text { elsewhere, although } \\
\text { methodological details } \\
\text { are not } \\
\text { provided }\end{array}$ & $\begin{array}{l}n=125(\mathrm{CSF} \\
\text { anti-NMDAR } \\
\text { and anti-VGKC); } \\
n=96(\mathrm{CSF} \\
\text { anti-AMPAR } \\
\text { and } \\
\left.\text { anti-GABA }{ }_{\mathrm{B}} \mathrm{R}\right)\end{array}$ & $\begin{array}{l}\text { Diagnoses included } \\
\text { schizophrenia, } \\
\text { delusional disorder, } \\
\text { acute polymorphic } \\
\text { psychotic disorder, } \\
\text { schizotypal disorder, } \\
\text { substance-induced } \\
\text { psychosis, schizoaffective } \\
\text { syndrome, and psychotic } \\
\text { syndromes in the context } \\
\text { of other disorders; } \\
\text { CSF+ cases included } \\
\text { schizophreniform } \\
\text { syndrome (2 anti-VGKC), } \\
\text { catatonic schizophreniform } \\
\text { syndrome (anti-NMDAR), } \\
\text { and schizoaffective } \\
\text { syndrome (anti-VGKC) }\end{array}$ & Not reported & Retrospective & None & $\begin{array}{l}\text { anti-NMDAR: } \\
\text { 1/125+; } \\
\text { anti-VGKC: } \\
\text { 3/125+; } \\
\text { anti-AMPAR: } \\
\text { 0/96+; } \\
\text { anti-GABA }{ }_{B} R: \\
0 / 96+\end{array}$ & Not reported \\
\hline $\begin{array}{l}\text { Steiner et al. } \\
{[10], 2013}\end{array}$ & $\begin{array}{l}\text { All antibody } \\
\text { testing was by } \\
\text { a commercial } \\
\text { immunoassay } \\
\text { (Euroimmun) }\end{array}$ & $\begin{array}{l}121 \text { had serum } \\
\text { testing and only } \\
\text { IgG-seropositive } \\
\text { cases had CSF } \\
\text { testing }(n=4)\end{array}$ & $\begin{array}{l}\text { Schizophrenia; } \\
\text { CSF+ cases included } \\
\text { disorganized } \\
\text { schizophrenia and } \\
\text { catatonic schizophrenia; } \\
\text { CSF- cases were } \\
\text { both paranoid } \\
\text { schizophrenia }\end{array}$ & $\begin{array}{l}\text { For whole } \\
\text { sample (most } \\
\text { of which did } \\
\text { not have CSF } \\
\text { results), mean } \\
\text { illness duration = } \\
9 \text { years; illness } \\
\text { duration of } \\
\text { CSF- cases = } 19 \\
\text { and } 21 \text { years; } \\
\text { illness duration } \\
\text { of CSF + cases = } \\
\sim 2 \text { years and } \\
\sim 4 \text { years }\end{array}$ & Retrospective & $\begin{array}{l}3 \text { control } \\
\text { groups } \\
\text { were } \\
\text { included: } \\
\text { major } \\
\text { depression } \\
\text { group, } \\
\text { borderline } \\
\text { personality } \\
\text { disorder } \\
\text { group, and } \\
\text { healthy } \\
\text { control group, } \\
\text { none of which } \\
\text { had CSF testing }\end{array}$ & $\begin{array}{l}\text { anti-NMDAR } \\
\text { NR1a subunit: } \\
\text { 2/2+; } \\
\text { anti-NMDAR } \\
\text { NR1a/NR2b } \\
\text { subunit: } \\
0 / 2+\end{array}$ & $\begin{array}{l}\text { In the } 1 \text { CSF+ } \\
\text { case that } \\
\text { underwent } \\
\text { immunotherapy, } \\
\text { psychotic } \\
\text { symptoms } \\
\text { improved } \\
\text { after 6-12 } \\
\text { weeks } \\
\text { of treatment }\end{array}$ \\
\hline $\begin{array}{l}\text { Oviedo-Salcedo } \\
\text { et al. [29], } 2018\end{array}$ & $\begin{array}{l}\text { All anti-neuronal } \\
\text { cell surface } \\
\text { antibody testing } \\
\text { was by a } \\
\text { commercial } \\
\text { immunoassay } \\
\text { (Euroimmun) }\end{array}$ & $\begin{array}{l}n=119(\mathrm{CSF} \\
\text { anti-NMDAR); } \\
n=114(\mathrm{CSF} \\
\text { anti-AMPA-1, } \\
\text {-2); } n=111(\mathrm{CSF} \\
\text { anti-CASPR2); } \\
n=110(\mathrm{CSF} \\
\text { anti-LGI } 1) ; \\
n=112(\mathrm{CSF} \\
\left.\text { anti-GABA }{ }_{\mathrm{B}} \mathrm{R}\right)\end{array}$ & $\begin{array}{l}\text { Diagnoses included } \\
\text { schizophrenia, } \\
\text { schizotypal disorder, } \\
\text { persistent delusional } \\
\text { disorders, acute and } \\
\text { transient psychotic } \\
\text { disorders, schizoaffective } \\
\text { disorders, and unspecified } \\
\text { nonorganic psychotic } \\
\text { disorders }\end{array}$ & $\begin{array}{l}\text { Mean duration } \\
\text { of illness }=\sim 62 \\
\text { months; } 44.3 \% \\
\text { of sample was } \\
\text { FEP; } 55.7 \% \text { had } \\
\text { recurrent illness; } \\
24.2 \% \text { had been } \\
\text { treated with } \\
\text { clozapine } \\
\text { previously }\end{array}$ & Retrospective & None & $\begin{array}{l}\text { Results were } \\
\text { negative in } \\
\text { all cases; }\end{array}$ & Not applicable \\
\hline
\end{tabular}

\section{Discussion}

There is currently inconsistent and conflicting evidence with respect to the role of anti-neuronal antibodies in the pathophysiology of psychosis in schizophrenia spectrum disorders, and this is likely in part due to methodological differences between studies. Nonetheless, there is currently little evidence from studies that only tested serum to suggest that antibodies directed against AMPAR, GABA ${ }_{B}$ R, LGI1, CASPR2, or DPPX, or 
IgA/IgM NMDAR antibodies, underlie the symptoms of a subset of patients with schizophrenia spectrum disorders, as most studies were either negative, or found positive results for both patients and healthy controls. However, there does appear to be some, albeit inconsistent, evidence implicating IgG antibodies directed against the NR1 subunit of the NMDA receptor in this context, and although the reason for the variable results of such studies remains unknown, it is likely multifactorial in nature. Possible contributory factors include the lack of a control group in many studies, variability in terms of diagnosis and illness chronicity (frequently not reported in detail), and differences among studies with respect to how antibodies were tested, making interpretation of the results difficult, particularly given that there is ongoing debate about the most sensitive and specific methods for antibody detection. Regarding the latter point, the most frequently used method in the reviewed studies (the commercially available fixed CBA) is believed to have high specificity but lower sensitivity $[14,41]$. Considering this, it is curious that those studies that found seropositivity in both patients and controls tended to use the commercial CBA, whereas those that only found seropositivity in patients used live CBAs. This arguable exception notwithstanding, overall none of these methodological issues appear to independently explain the inconsistent findings. With this in mind, perhaps one of the biggest issues relates to the subjective nature of the interpretation of antibody testing [27], rather than to the particular antibody detection method used. It has been suggested that relying on any single method of detecting antibodies in serum may increase the risk of false-positive and false-negative results [27]. Notably, while three studies that included multiple antibody detection methods were entirely negative $[19,26,27]$, one study that included both live and fixed CBAs found seropositivity using both assays, but the authors do highlight that the choice of CBA influenced the results [14]. While the selection and interpretation of antibody detection methods may be an ongoing point of debate, the inclusion of a control group can help make sense of findings and assist in safeguarding against the misinterpretation of false-positive results. As such, perhaps the most informative serum studies that support the notion that a small subset of patients with a primary psychotic disorder possess anti-neuronal antibodies are those that found antibody positivity in a small number of patients, but not in healthy controls. Still, it is interesting that key methodological features differ between these studies, and moreover, do not clearly set them apart from other reviewed studies that yielded ambiguous or negative results.

Perhaps most importantly, the sensitivity and specificity associated with testing serum for anti-neuronal antibodies is lower than that of CSF testing, and in general should not be relied upon for the clinical diagnosis of $\mathrm{AE}$ $[5,7]$. One possible exception to this is that CSF testing may be less sensitive for LGI1 and CASPR2 antibodies [42]. Relatedly, peripheral antibodies are theoretically not directly pathogenic, and rather must infiltrate the CSF to act on neural tissue. As such, the effects of antibodies in the serum may depend on the integrity of the blood-brain barrier in individual cases [43]; a variable not considered or studied in most of the aforementioned papers. Given the generally superior sensitivity and specificity associated with testing CSF in comparison to serum in the diagnosis of $\mathrm{AE}$, we argue that the most clinically relevant studies to date are those that have included CSF data, and particularly those that have included both CSF and serum data. In comparison to the three positive studies, the reason for the negative results in the study by Oviedo-Salcedo et al. [29] remains unclear, particularly given that it included a reasonably large sample comprised of a variety of primary psychotic disorder diagnoses, including some found to be associated with antibody positivity in other studies (i.e. schizophrenia, schizoaffective disorder, and "acute and transient psychotic disorder"), and given that it tested for a fairly comprehensive panel of anti-neuronal antibodies, using the same commercially available CBA frequently used in other studies. As mentioned, it is possible that differences in the interpretation of the assay may have played a role. Nonetheless, the results of the CSF studies taken as a whole suggest that in rare cases, $\mathrm{AE}$, and particularly anti-NMDAR encephalitis, may be misdiagnosed as a primary psychotic disorder, at least early in the course of the illness. However, given that the duration of untreated psychosis was either quite short or unclear for the CSFpositive patients in these studies, neurological symptoms either did develop or may have soon developed in such cases, making it unlikely that such patients would have continued to be diagnosed with a primary psychotic disorder for long periods of time. As mentioned previously, non-psychiatric symptoms that should alert clinicians to the possibility of anti-NMDAR encephalitis include cognitive impairment, an altered level of consciousness, abnormal movements, seizures, and eventually autonomic instability.

What is not clear from the evidence is whether seemingly chronic or treatment-resistant schizophrenia popu-
Colijn/Ismail 
lations have an unappreciated autoimmune burden, contributing to the lack of response to treatment. It is possible that monosymptomatic forms of $\mathrm{AE}$ exist that involve purely psychotic presentations for much longer periods of time than previously expected. Interestingly, an observational anti-NMDAR cohort study supports this possibility [44], as psychiatric symptoms, including psychosis, were found in isolation in a small subset of AE patients for as long as 60 weeks, without the development of neurological symptoms. These individuals ranged in age between 13 and 46 years, with a mean age of approximately 23 years, and their symptoms included delusions, auditory and visual hallucinations, mania, and aggression, among others. Immunotherapy was given in four of five cases, and all four patients reportedly achieved and maintained a full recovery at 24 - to 37 -month follow-up. While approximately $0.9 \%$ of this $\mathrm{AE}$ cohort had only psychiatric symptoms, this type of study is unable to provide any information regarding the prevalence of misdiagnosed $\mathrm{AE}$ in schizophrenia populations. Rather, studies screening the serum and CSF for the aforementioned antibodies in chronic and treatment-resistant schizophrenia patients are needed to address this question. Doing so in treatment-resistant patients, and particularly in clozapine-resistant patients, is especially important, as few evidence-based treatment options exist beyond clozapine in the context of treatment resistance [9], and those identified as having a clinically actionable autoimmune component to their illness may benefit from immunotherapy. Moreover, treatment-resistant patients may represent an enriched population with respect to the presence of antineuronal antibodies, as such individuals presumably have unique pathophysiological characteristics underlying their illness, in comparison to those who respond to antipsychotic therapy.

Given the real-world implications of determining the potential association between clinically actionable auto- immune disease and treatment-resistant symptoms in the context of primary psychotic disorders, it is recommended that future research focus on prospectively screening both the serum and CSF of treatment-resistant patients for the aforementioned antibodies commonly implicated in AE. Additionally, incorporating other biomarker data into such research may allow for the further subcategorization of patients, and in turn improve our ability to predict which individuals are most likely to have an autoimmune process underlying their illness. Moreover, such research may provide the foundation for the eventual development of clinical trials of various immunotherapies in AE patients with exclusively psychotic symptoms.

\section{Statement of Ethics}

The authors have no ethical conflicts to disclose.

\section{Disclosure Statement}

Dr. Ismail reports grants and personal fees from Janssen and personal fees from Otsuka/Lundbeck Alliance, Avanir, Sunovion, Lilly, and Pfizer, all of which are unrelated to the submitted work. Dr. Colijn reports no financial relationships with commercial interests.

\section{Funding Sources}

There are no funding sources related to the preparation of this paper.

\section{Author Contributions}

Both Dr. Colijn and Dr. Ismail contributed to the preparation, writing, and editing of the paper.

\section{References}

1 Addington D, Abidi S, Garcia-Ortega I, Honer WG, Ismail Z. Canadian Guidelines for the Assessment and Diagnosis of Patients with Schizophrenia Spectrum and Other Psychotic Disorders. Can J Psychiatry. 2017 Sep;62(9): 594-603.

2 Owen MJ, Sawa A, Mortensen PB. Schizophrenia. Lancet. 2016 Jul;388(10039): 86-97.

3 Khandaker GM, Cousins L, Deakin J, Lennox BR, Yolken R, Jones PB. Inflammation and immunity in schizophrenia: implications for pathophysiology and treatment. Lancet Psychiatry. 2015 Mar;2(3):258-70.

4 Pouget JG. The Emerging Immunogenetic Architecture of Schizophrenia. Schizophr Bull. 2018 Aug;44(5):993-1004.

5 Lancaster E. The Diagnosis and Treatment of Autoimmune Encephalitis. J Clin Neurol. 2016 Jan;12(1):1-13.

6 Hao Q, Wang D, Guo L, Zhang B. Clinical characterization of autoimmune encephalitis and psychosis. Compr Psychiatry. 2017 Apr; 74:9-14.
7 Honnorat J, Plazat LO. Autoimmune encephalitis and psychiatric disorders. Rev Neurol (Paris). 2018 Apr;174(4):228-36.

8 Graus F, Titulaer MJ, Balu R, Benseler S, Bien CG, Cellucci T, et al. A clinical approach to diagnosis of autoimmune encephalitis. Lancet Neurol. 2016 Apr;15(4):391-404.

9 Remington G, Addington D, Honer W, Ismail Z, Raedler T, Teehan M. Guidelines for the Pharmacotherapy of Schizophrenia in Adults. Can J Psychiatry. 2017 Sep;62(9): 604-16. 
10 Steiner J, Walter M, Glanz W, Sarnyai Z, Bernstein HG, Vielhaber S, et al. Increased prevalence of diverse N-methyl-D-aspartate glutamate receptor antibodies in patients with an initial diagnosis of schizophrenia: specific relevance of IgG NR1a antibodies for distinction from N-methyl-D-aspartate glutamate receptor encephalitis. JAMA Psychiatry. 2013 Mar; 70(3):271-8.

11 Dahm L, Ott C, Steiner J, Stepniak B, Teegen B, Saschenbrecker S, et al. Seroprevalence of autoantibodies against brain antigens in health and disease. Ann Neurol. 2014 Jul; 76(1):82-94.

12 Hammer C, Stepniak B, Schneider A, Papiol S, Tantra M, Begemann M, et al. Neuropsychiatric disease relevance of circulating antiNMDA receptor autoantibodies depends on blood-brain barrier integrity. Mol Psychiatry. 2014 Oct;19(10):1143-9.

13 Pathmanandavel K, Starling J, Merheb V, Ramanathan S, Sinmaz N, Dale RC, et al. Antibodies to surface dopamine-2 receptor and $\mathrm{N}$-methyl-D-aspartate receptor in the first episode of acute psychosis in children. Biol Psychiatry. 2015 Mar;77(6):537-47.

14 Jézéquel J, Rogemond V, Pollak T, Lepleux M, Jacobson L, Gréa H, et al. Cell- and Single Molecule-Based Methods to Detect Anti-NMethyl-D-Aspartate Receptor Autoantibodies in Patients With First-Episode Psychosis From the OPTiMiSE Project. Biol Psychiatry. 2017 Nov;82(10):766-72.

15 Lennox BR, Palmer-Cooper EC, Pollak T, Hainsworth J, Marks J, Jacobson L, et al.; PPiP study team. Prevalence and clinical characteristics of serum neuronal cell surface antibodies in first-episode psychosis: a case-control study. Lancet Psychiatry. 2017 Jan;4(1):42-8.

16 Scott JG, Gillis D, Ryan AE, Hargovan H, Gundarpi N, McKeon G, et al. The prevalence and treatment outcomes of antineuronal antibody-positive patients admitted with first episode of psychosis. BJPsych Open. 2018 Mar;4(2):69-74.

17 Rhoads J, Guirgis H, McKnight C, Duchemin AM. Lack of anti-NMDA receptor autoantibodies in the serum of subjects with schizophrenia. Schizophr Res. 2011 Jul;129(2-3):213-4.

18 Haussleiter IS, Emons B, Schaub M, Borowski $\mathrm{K}$, Brüne $\mathrm{M}$, Wandinger $\mathrm{KP}$, et al. Investigation of antibodies against synaptic proteins in a cross-sectional cohort of psychotic patients. Schizophr Res. 2012 Sep;140(1-3):258-9.

19 Masdeu JC, González-Pinto A, Matute C, Ruiz De Azúa S, Palomino A, De Leon J, et al. Serum IgG antibodies against the NR1 subunit of the NMDA receptor not detected in schizophrenia. Am J Psychiatry. 2012 Oct; 169(10):1120-1.

20 Çoban A, Ismail Küçükali C, Bilgiç B, Yalçınkaya N, Haytural H, Ulusoy C, et al. Evaluation of incidence and clinical features of antibody-associated autoimmune enceph- alitis mimicking dementia. Behav Neurol. 2014;2014:935379.

21 Masopust J, Andrýs C, Bažant J, Vyšata $O$, Kuca K, Vališ M. Anti-NMDA receptor antibodies in patients with a first episode of schizophrenia. Neuropsychiatr Dis Treat. 2015 Mar;11:619-23.

22 de Witte LD, Hoffmann C, van Mierlo HC, Titulaer MJ, Kahn RS, Martinez-Martinez P; European Consortium of Autoimmune Mental Disorders (CAIMED). Absence of $\mathrm{N}$ Methyl-D-Aspartate Receptor IgG Autoantibodies in Schizophrenia: The Importance of Cross-Validation Studies. JAMA Psychiatry. 2015 Jul;72(7):731-3.

23 van Mierlo $\mathrm{HC}$, van Coevorden-Hameete $\mathrm{MH}$, Munting LP, de Graaff E, de Witte L; GROUP investigators. No evidence for the presence of neuronal surface autoantibodies in plasma of patients with schizophrenia. Eur Neuropsychopharmacol. 2015 Dec;25(12):2326-32.

24 Schou M, Sæther SG, Borowski K, Teegen B, Kondziella D, Stoecker W, et al. Prevalence of serum anti-neuronal autoantibodies in patients admitted to acute psychiatric care. Psychol Med. 2016 Dec;46(16):3303-13.

25 Timucin D, Ozdemir O, Parlak M. The role of NMDAR antibody in the etiopathogenesis of schizophrenia. Neuropsychiatr Dis Treat. 2016 Sep;12:2327-32.

26 Chen $\mathrm{CH}$, Cheng MC, Liu CM, Liu CC, Lin $\mathrm{KH}, \mathrm{Hwu}$ HG. Seroprevalence survey of selective anti-neuronal autoantibodies in patients with first-episode schizophrenia and chronic schizophrenia. Schizophr Res. 2017 Dec;190: 28-31.

27 Hara M, Martinez-Hernandez E, Ariño H, Armangué T, Spatola M, Petit-Pedrol M, et al. Clinical and pathogenic significance of $\operatorname{IgG}$, IgA, and IgM antibodies against the NMDA receptor. Neurology. 2018 Apr;90(16):e1386-94.

28 Mantere O, Saarela M, Kieseppä T, Raij T, Mäntylä T, Lindgren M, et al. Anti-neuronal anti-bodies in patients with early psychosis. Schizophr Res. 2018 Feb;192:404-7.

29 Oviedo-Salcedo T, de Witte L, Kümpfel T, Kahn RS, Falkai P, Eichhorn P, et al. Absence of cerebrospinal fluid antineuronal antibodies in schizophrenia spectrum disorders. Br J Psychiatry. 2018 May;212(5):318-20.

30 Steiner J, Teegen B, Schiltz K, Bernstein HG, Stoecker W, Bogerts B. Prevalence of Nmethyl-D-aspartate receptor autoantibodies in the peripheral blood: healthy control samples revisited. JAMA Psychiatry. 2014 Jul; 71(7):838-9.

31 Tsutsui K, Kanbayashi T, Tanaka K, Boku S, Ito $\mathrm{W}$, Tokunaga J, et al. Anti-NMDA-receptor antibody detected in encephalitis, schizophrenia, and narcolepsy with psychotic features. BMC Psychiatry. 2012 May; 12(1):37.

32 Dickerson F, Stallings C, Vaughan C, Origoni A, Khushalani S, Yolken R. Antibodies to the glutamate receptor in mania. Bipolar Disord. 2012 Aug; 14(5):547-53.

33 Zandi MS, Irani SR, Lang B, Waters P, Jones $\mathrm{PB}, \mathrm{McKenna} \mathrm{P}$, et al. Disease-relevant autoantibodies in first episode schizophrenia. J Neurol. 2011 Apr;258(4):686-8.

34 Beck K, Lally J, Shergill SS, Bloomfield MA, MacCabe JH, Gaughran F, et al. Prevalence of serum N-methyl-D-aspartate receptor autoantibodies in refractory psychosis. Br J Psychiatry. 2015 Feb;206(2):164-5.

35 Ando Y, Shimazaki H, Shiota K, Tetsuka S, Nakao K, Shimada T, et al. Prevalence of elevated serum anti-N-methyl-D-aspartate receptor antibody titers in patients presenting exclusively with psychiatric symptoms: a comparative follow-up study. BMC Psychiatry. 2016 Jul;16(1):226.

36 Gaughran F, Lally J, Beck K, McCormack R, Gardner-Sood P, Coutinho E, et al. Brain-relevant antibodies in first-episode psychosis: a matched case-control study. Psychol Med. 2018 Jun;48(8):1257-63.

37 Ezeoke A, Mellor A, Buckley P, Miller B. A systematic, quantitative review of blood autoantibodies in schizophrenia. Schizophr Res. 2013 Oct;150(1):245-51.

38 Pearlman DM, Najjar S. Meta-analysis of the association between $\mathrm{N}$-methyl-d-aspartate receptor antibodies and schizophrenia, schizoaffective disorder, bipolar disorder, and major depressive disorder. Schizophr Res. 2014 Aug; 157(1-3):249-58

39 Pollak TA, McCormack R, Peakman M, Nicholson TR, David AS. Prevalence of anti-Nmethyl-D-aspartate (NMDA) receptor [corrected] antibodies in patients with schizophrenia and related psychoses: a systematic review and meta-analysis. Psychol Med. 2014 Sep;44(12):2475-87.

40 Endres D, Perlov E, Baumgartner A, Hottenrott T, Dersch R, Stich O, et al. Immunological findings in psychotic syndromes: a tertiary care hospital's CSF sample of 180 patients. Front Hum Neurosci. 2015 Sep;9: 476.

41 Najjar S, Steiner J, Najjar A, Bechter K. A clinical approach to new-onset psychosis associated with immune dysregulation: the concept of autoimmune psychosis. J Neuroinflammation. 2018 Feb;15(1):40.

42 Gadoth A, Pittock SJ, Dubey D, McKeon A, Britton JW, Schmeling JE, et al. Expanded phenotypes and outcomes among 256 LGI1/ CASPR2-IgG-positive patients. Ann Neurol. 2017 Jul;82(1):79-92.

43 Al-Diwani AA, Pollak TA, Irani SR, Lennox BR. Psychosis: an autoimmune disease? Immunology. 2017 Nov;152(3):388-401.

44 Kayser MS, Titulaer MJ, Gresa-Arribas N, Dalmau J. Frequency and characteristics of isolated psychiatric episodes in anti-Nmethyl-d-aspartate receptor encephalitis. JAMA Neurol. 2013 Sep;70(9):1133-9. 